\title{
The Urgency of Education of Comprehension of Pluralism in Religion for Candidates of Bridegroom in Blitar Regency to Create Sakinah Family
}

\author{
M. Dimyati Huda ${ }^{1}$ \\ \{dimyatihuda99@gmail.com ${ }^{1}$ \} \\ Lecturer Comparative Religion IAIN Kediri ${ }^{1}$
}

\begin{abstract}
The urgency of education of comprehension of pluralism in religion for candidates of bridegroom in Blitar Regency to achieve peaceful loving family life illustrates comprehension of pluralism in religion and explains the importance of comprehension of pluralism in religion for candidates of bridegroom in Blitar Regency. This study uses qualitative descriptive method with the findings and discussion that some candidates of bridegroom have understood the meaning of pluralism in religion for life in society and some have not yet understood it. The implementation of enhancement of comprehension of pluralism in religion is carried out when attending the course for candidates of bridegroom which is held with one to one and independent course. Recommendations for organizing premarital course should follow the guidance and implementation of technical guidance and also incorporate perception of religious pluralist in order to make moderation in religion first priority. The enhancement of comprehension of pluralism in religion can be carried out with education and training activities, seminars, focus group discussions, and workshops.
\end{abstract}

Keywords: Education, Pluralism in Religion, Peaceful Loving Family Life.

\section{Introduction}

\subsection{Background}

The comprehension of pluralism in religion is very important for the life of Indonesian people. The topic of pluralism in religion has been studied since 1980. The importance of this discussion cannot be separated from the objective conditions of Indonesian people who have high diversity in terms of life, religion and cultural behavior to carry out the functions of life. The large population of Indonesia with various ethnic groups and cultures is united with the national foundation of Pancasila which is a unifier in enhancing its role and fostering social and state life.

Family as the smallest element of society has a very important role in social life. Family is formed from a marriage bond that is protected by the Marriage Law. The Marriage Law of 1974 Chapter 1 Article 1 [22] states that "marriage is a deep commitment between man and woman as husband and wife with the aim of forming a happy and eternal family based on the belief in the one and only God and this is continued in Article 2 stating that marriage is recorded in accordance with the applicable law. The marriage registration service for Muslims is carried out at the Office of Religious Affairs. 
Based on the Regulation of the Director General of Islamic Community Guidance Number: DJ. II / 542 of 2013 [18] about Guidelines for Pre-Marriage Course article I states that "pre-marital course" is providing knowledges, comprehensions, skills and awarenesses to the married-age teenagers about married life and family. In order to create a sakinah family that is "a family based on a legal marriage, able to fulfill spiritual and material needs in harmony and balance, filled with an atmosphere of affection between the intern of family and environment, able to understand, practice and deepen the values of faith, piety and morality.

Related to the above, that is the decision of the Director General of Islamic Community Guidance Number 379 of 2018 about the implementation instructions of pre-marital course for bridegroom shows that family is the most important foundation in the development of human resource. A strong and resilient family is in the interest of nation so that the pre-marital course is carried out to create the ideal family.

The course activities, the guidance for the bridegroom, have not been maximally conducted proven by the statements of some people who have attended the pre-marital courses. They still consider that the pre-marital course is only a formal requirement, so that the implementation has not been maximized. Divorce lawsuits at the Blitar Religious Court increased from 2010 to 2019. Divorce took place because of conflicts that were triggered by economic problems and religious comprehension that were still low.

The conflict that arose in the Pikatan area of Wonodadi District, Blitar Regency, which destroyed the place of worship was not because of conflict among religious communities. However, it was triggered by the problem of bad family relation that required the role of a religious leader to solve it. To create peace, it is necessary to increase the comprehension of the value of faith as a guide to the path of happiness that grows from small families and can influence the creation of civil society, that is, a civilized society in social life in the 4.0 era so that a universal religious education is needed to solve problem of life.

\subsection{Formulation of the problem}

The researcher emphasizes formulation of the problem as follows:

1. How is the comprehension of pluralism in religion for the candidates of bridegroom in Blitar Regency?

2. How is the implementation of enhancing the comprehension of pluralism in religion to the candidates of bridegroom in Blitar Regency?

3. How important is the comprehension of pluralism in religion for the candidates of bridegroom in Blitar Regency?

\subsection{Research purposes}

The objectives of this study are:

1. To describe the comprehension of pluralism in religion for the candidates of bridegroom in Blitar Regency

2. To describe the implementation of enhancement of the comprehension of pluralism in religion for the candidates of bridegroom groom in Blitar Regency

3. To describe the importance of comprehension of pluralism in religion for the candidates of bridegroom in Blitar Regency 


\subsection{Benefits of research}

This research will be useful as a material for further studies on the enhancement of comprehension of pluralism in religion for community especially for candidates of bridegroom and as a foothold for decision makers to establish several matters relating to pluralism in religion in creating social or civil society.

\section{Theory review}

\subsection{Pluralism in religious life}

According to Nurcholis Madjid [16], pluralism is a value system that looks positively optimistic about pluralism by accepting a reality and doing the best based on that reality. In Islam the context of pluralism of humanity has been universally taught and can be developed in accordance with the conditions and situations at any time. In regulating religious life, the Koran embeds a message of tolerance which means "There is no compulsion to enter religion (Islam), in fact, the right path is clear from the wrong path (Qs. 2: 256) and if your Lord desires surely all people on earth will believe entirely." So, do you (want to) force people to become believers? (QS: 10; 99) and say the truth is coming from your Lord so whoever wants to believe, please believe and whoever wants to disbelieve, let it be infidel. (QS.18: 29), for you is your religion and for me is my religion (QS.109: 6).

History records that when the Prophet Muhammad (PBUH) was in Medina the social order was well organized and accommodated to all the interests of the community, both Muslims and Non-Muslims. The Medina Charter introduces a treaty that guarantees the safety of life, property and religion of the local population, an agreement made by Umar Bin Khotob with the inhabitants of Jerusalem, after the holy city was liberated by Muslim soldiers. The verses of the Koran which show the value of pluralism are: "O people, we have created you from men and women, and made you peoples and tribes to know one another. Surely the most noble among you by Allah is the most pious among you. Indeed, Allah is All Knowing and All Knowing.

Islam is a religion of humanity which has the same ideals and is in line with universal humanitarian ideals. Religions that thrive in Indonesia are protected by law so that tolerance between religions is guaranteed by state. As Alwi Shihab [3] said that the concept of pluralism in religion should be applied in Indonesia with the condition of a strong commitment to each religion. A pluralist in interacting with various religions is not only required to open up and respect his partners of dialogue, but also must be commited to his religion so as to avoid religious relativism that is not in line with the concept of unity in diversity.

\subsection{Enhancement of comprehension in religion}

The enhancement of comprehension in religion has been need of individuals in society and religion and according to Elizabeth [6] this is a symptom that is often found everywhere so that it helps human efforts to create a scientific picture. While Honig [12] said that religion is something that is trusted. The belief here is not only describing and explaining the sacred and unseen nature of the supernatural, but more important is that the belief tells that the supernatural is associated with the real nature. Furthermore Zuli Qodir [24] states that 
sociologically something is called religion if it has five conditions including: (1) religion has extraordinary power so that it is feared and asked for protection or help. (2) religion has systemic and systematic series of ritual ways (worship) as a path to what is cultured, (3) the existence of a person as a sacred mission carrier in the midst of society. (4) the presence of worshipers who preserve the prophetic holy message (5) the existence of the holy book which is used as a reference for ritual activities.

According to Taufiq Abdullah [19] the intellectual dimension in religion is indispensable and absolutely necessary because it can indicate the level of comprehension of a person about his religious doctrine. In other words, religious quality of a person can be determined, one of them, by her comprehension about her religion.

Besides for individual and collective life, religion also has a function as a medium for individuals to socialize themselves in the midst of society. Every individual needs a guiding value system to direct all his activities in society. Therefore, religious knowledge is very important as a foundation for social and moral value systems.

According to Abdurrahman Mas'ud [1] whole human education taught by the Prophet Muhammad provided a positive solution to the problems of the people. The Prophet provided education to create noble man by prioritizing the teaching of monotheism and offered a sharpening of social sensitivity that originated from revelation, heart, conscience, reason, soul and social reality.

\subsection{The role of education for candidates of bridegroom}

Humans basically need education as Nogis Tangkilisan [20] stated that humans need education and through education they can develop themselves. The statement shows that education plays an important role for the candidate of bridegroom it is necessary for the candidate of bridegroom to enhance their knowledge to create a sakinah family in the 4.0 era. According to Azizy [4] education in term of language is the process of training and developing knowledges, skills, minds, characters etc, conducted especially by formal schooling. Meanwhile, Faisal [8] stated that education is the process of transferring values of knowledge and skills from the older generation to the younger generation so the older generation can live their lives.

By obtaining education, people will easily obtain a more decent life with their competencies by participating in guidances, seminars, discussion group forums, and workshops. A society that has civilization and morality and also loyal and obedient to the religious law is a society desired by civil society that places education and morality as the main components in society.

\section{Research method}

\subsection{Method}

This study uses descriptive qualitative method to explore social phenomena related to the comprehension of pluralism in religion for the candidates of bridegroom in creating a sakinah family. Descriptive research according to Arikunto [2] is research aimed to describe state or status of phenomena. Furthermore, according to Kirk and Miller in Moleong [15] descriptive research is a particular tradition in social science that is fundamentally dependent on human 
observations both in the region and its terminology. While qualitative research according to Bodgan [5] is a research procedure that produces descriptive data in the form of written or oral words from people and observable behavior.

From the above statement it can be concluded that qualitative research is research that intends to understand what phenomenas are experienced by subjects of research such as behavior, perception, motivation and action holistically and with descriptions in the form of words and language in a natural context in depth.

\subsection{Focus of the research}

This research focuses on the determined problems as Faisal [7] said that focus of the research is the initial subject matter chosen to be studied and how to focus it. This is in line with Moleong [15] arguing that focus of the research is basically the main problem that comes from the experience of researchers or through the knowledge gained from scientific literature. Focus of the problem should be made because of facts on the field which is full of variants and unexpected things therefore it is limited to sharpen the focus. Besides, it will also facilitate researchers in collecting data in accordance with problems on the fields.

\subsection{Data collection}

The stage of data collection is carried out by entering into the location, being in the location by communicating effectively in order to obtain information that is useful for researchers to be observed and studied so that it is more perfect in data collection using interviews, observations and documentation which is related to the research.

\subsection{Type and source of data}

Data used in this research is primary data which is directly obtained from the field with direct interviews of informal sources such as candidates of bridegroom, employees of the Ministry of Religion Affair in Blitar Regency. The other type of data is secondary data as a support to complete primary data and is obtained from regulations, archives, documents relating to the implementation of religion comprehension enhancement of bridegroom candidates.

\subsection{Data collection technique}

Data collection techniques was carried out with effective interviews in accordance with the statement of Arikunto [2] who said that interviews conducted effectively are interviews conducted in the shortest possible period of time and data can be obtained as much as possible, the language must be clear, directed, the atmosphere must remain relax so that data can be obtained accurately. Next is the observation technique, which is a deliberate and systematic study of natural phenomena by observation and recording. Furthermore, the technique of collecting data through documentation is to collect documentation to gather various information relevant to the problem and focus of the research. 


\subsection{Validity of data}

In qualitative research, validity of the data is used as a benchmark or standard to see the truth of the research. In this case the researcher refers to the statements of Lincoln and Guba [14] and the opinion of Patton [17] who said that to check the validity of the data by using a validity check which consists of four criterias, namely the degree of trust, intelligence, dependability and certainty.

\subsection{Data analysis}

Data analysis is a process that is carried out continuously with creative thinking through organizing and sorting data into patterns, categories and basic description units so that they can find themes to formulate hypothetical themes as suggested by the data. In this case the researcher reduces the data by selecting and sorting and focusing on the process of simplification and transformation of rough data obtained by researchers from interviews, observations and documentation. In order to make the data easily analyzed, classification is made and coded on the research object so that the research findings can be useful as substantive theories.

\section{Discussion}

\subsection{Comprehension of pluralism in religion for candidates of bridegroom in blitar regency}

The candidates of bridegroom in Blitar Regency in comprehending pluralism in religion is determined highly by their educational background, religion, culture and environment. This is in line with the definition of pluralism according to Gerald O'Collins \& Edward G. Farrugia [9] who said that pluralism is a philosophical view that does not want to reduce everything to the last principle but accepts the existence of diversity. Pluralism covers the fields of cultural, political and religious. In the field of culture in the Blitar Regency there is a custom to determine the counting of good days when marriage will take place. The culture is believed by the community as a guiding belief in their lifestyle. If there is a cultural violation then it is not considered to be a sin but an uncivilized behavior.

The pattern of community life in Blitar district is very heterogeneous so it needs to respect culture of other people so that relationships can be created properly and not easily profiled as an event in the village of Pikatan Wonodadi District. In the beginning, the incident was occurred from an ineffective communication process between the husband's family and his wife's family, so that it brought the impact of the anger of residents due to the destruction of the place of worship. Conflict can be resolved properly by religious leaders and with a clear explanation that the act of destroying place of worship is an uncivilized behavior. Any religion never teaches error and always conveys moral messages of mutualism in society.

Society according to Hendropuspito [11] is a collection of patterns, relationships, various traditions, individual and public rights which is organized and preserved in all time. While religion is a social system created by adherents who pivots on a non-empirical provision and is trusted and empowered to achieve safety for themselves and society. Related to this matter, religion is one of the important aspects to unite the aspirations of humans in the most sublime 
societies, Religion is a source of morality and inner peace that can make humans noble and civilized. [21]

According to Hasan Shadely [10] thing that must exist in the social life is the relationship of mutual relations with full awareness. Religion is able to perform social functions through the values of comprehension of pluralism in religion as a form of integration between members of society to unite towards the desired goals. Based on this, when there was a destruction of place of worship in Blitar Regency, precisely in Mushola of Pikatan Village, Wonodadi District, Blitar regency, in fact it was not because of conflict in comprehension of pluralism in religion, but because communication of the families was not harmonious and could be reconciled by religious leaders. For this reason, the course of comprehension of pluralism in religion for candidates of bridegroom is still needed for the continuity of mutualism in society.

\subsection{Implementation of enhancement of comprehension of pluralism in religion for candidates of bridegroom in Blitar regency}

Candidates of bridegroom in Blitar Regency, from 2013 to 2018, after registering their marriage registration at the Office of Religious Affairs then they followed the course for candidates of bridegroom for 16 hours with basic group materials, core groups and support groups. Subject of the core group is implementing functions of family, able to understand functions of family, able to explain contextually functions of family with family life experiences and able to implement in family life through action plans with functions of religion as main material. The description of main material is putting in function the values of Islamic teachings in family life, maintain human nature and strengthen monotheism by developing morals.

Meanwhile, the decision of the Director General of Social Affairs Number 379 / Year 2018 [13] regarding the instructions for the implementation of prenuptial marriage guidance for bridegroom is also carried out with the number of guidance hours of 16 hours which is conducted in two consecutive days or according to the specified time.

The material includes: (1) building a foundation for a sakinah family, that is, an ideal family, (2) planning a solid marriage towards a sakinah family on the basis that two human beings are brought together to lead to the same goal of forming a sakinah family. (3) Marriage dynamics are described by comprehending that marital life is not static but is always dynamic based on the development of information and technology or in tune with the dynamics of the times. (4) Based on Maslow's theory of needs that is to meet needs by giving a moral message to every candidates of bridegroom about the needs of life describing that the needs of every human being are universal, (5) family health that is to maintain the continuity of a prosperous family for candidate of bridegroom to receive materials relating to the importance of maintaining health, (6) Building a quality generation that is a generation that can create a civilized society, a society that respects the interests of others, upholds morality and that can be implemented by comprehending pluralism in religion, (7). Family resilience in facing contemporary challenges while still holding fast to religious beliefs so that all challenges can be overcome properly. (8) Recognizing and using the law to protect family marriages, the material is conveyed so that every candidates of bridegroom gets protection from her marriage process towards the same goal of building a sakinah family.

The enhancement of comprehension of pluralism in religion for candidates of bridegroom in Blitar regency is carried out with guidance as stated in the technical guidance of implementation of course in each district carried out by the Religious Affairs Office, 
amounting to 22 KUA in each district. In the implementation, the cost is Rp. 400,000 per pair and Rp. 200,000 per person, and for an independent tutoring the cost is Rp. 50,000. Source of the budget is obtained from the budget implementation list of the religious affairs office of Blitar Regency.

Course in the office of the ministry of religion is done one to one and independently carried out at the Religious Affairs office with a total of 25 bridegroom couples or 50 participants. Meanwhile, if the number does not reach 50 participants, the implementation will be carried out at the Office of the Ministry of Religion in the district where participants are joined from several sub-districts. For candidates who cannot attend one to one course, the implementation is carried out with independent course.

The Independent course is carried out by the religious affairs office whose typology is D1 and D2 with the following conditions:

1. Participants receive an independent reading book published by the Ministry of Religion

2. In time of registration, candidates of bridegroom get the basics of marriage, building a sakinah family and regulations related to family problems

3. Candidates of bridegroom come to the health center to get guidance about reproductive health, healthy lifestyle, family health as evidenced by a certificate of guidance from the health center.

4. Candidates of bridegroom receive guidance from 2 advisors that can be carried out by counselors of counseling agencies for marital guidance and preservation (BP4), headman, Islamic religious counselor, ulama, psychology, or education practitioner in the area of residence or an affordable place with materials : building family relationship and fulfill family needs for 2 hours and preparing a quality generation for 2 hours as evidenced by a statement signed by the advisor.

Related with the provisions above, in fact, candidates of bridegroom did not get the material for 2 hours and they even gave a form signed by two advisors. As said by candidates of bridegroom that the course is only as a formality to meet the requirements of marriage registration after registering at the Office of Religious Affairs.

\subsection{The importance of education of comprehension of pluralism in religion for candidates of bridegroom in Blitar regency}

Education of comprehension of pluralism in religion in Blitar district is highly needed considering from the observation of researcher that the course is not optimal and is still considered to be a formality to meet the requirements of marriage. Even the implementation of independent course that should be given for 16 hours was not fulfilled because candidates of bridegroom groom when facing the advisor only asked for the signature of the provided form. Whereas purpose of the course is to enhance their knowledge to prepare a sakinah family in a civilized society.

Society according to Poerwadarminta [23] is a group of people who live together in a certain place. This group of people comes from families who play a very important and strategic role in creating prosperous community. Therefore, the importance of education of comprehension of pluralism in religion that is to carry out its function as abdilah and kholifatul fil ardhi can be realized properly.

Candidates of bridegroom who follow one to one or independent course are students who will be enhanced about their religion competences and their knowledge related to sakinah families and reproductive health thereby they become good human being. In the process of education to create good human being, education of religious humanist is needed as 
Abdurrahman Mas'ud [1] stated that religious humanist with education of pluralism (respecting differences) given to students will make khalifatullah or insan kamil. Islamic teachings or education in Islam provides support for pluralism and cross-culture. Islam supports human brotherhood, opposes racial, ethnic and primordial prejudice in order to create a civilized society that respect differences. As in the verse of the AL-Qur'an which means: O man we actually created you from a man and a woman and made nations and tribes, so that you know one another, in fact the most noble person in the sight of Allah SWT is the most pious among you. Indeed, Allah is all knowing and all knowing (Al Hujrat: 13)

\section{Conclusions}

\subsection{Summary}

From this explanation, the researcher can conclude that the comprehension of pluralism in religion for candidates of bridegroom in Blitar regency is still low. Not all of them comprehend the meaning and and function of comprehension of pluralism in religion for families in society. Implementation of enhancement of comprehension of pluralism in religion for candidates of bridegroom is carried out when they attend course held with one to one or independent course. Candidates of bridegroom in Blitar regency consider important for education of comprehension of pluralism in religion to create a civilized society.

\subsection{Recommendation}

1. Implementation of course for candidates of bridegroom should be carried out in accordance with the guidelines for implementing course and incorporating material of enhancement of comprehension of pluralism in religion as moderation in religion to create a sakinah family.

2. Participation of society is necessary to enhance self-awareness for enhancing comprehension of pluralism in religion in order to create civilized society by conducting moderation in religion through education and training, seminars, focus group discussions, and workshops.

\section{References}

[1] Abdurrahman Mas'ud.: initiate non-dichotomy education format. Gama Media. Yogyakarta

[2] Suharsimi. Study of a practical approach.Rineka Cipta. Yogyakarta.(1999)

[3] Alwi Shihab : Islam Inclusive. Mizan. Jakarta.

[4] Azizy, Qodri : Education of religion to build social ethic. Aneka Ilmu. Semarang. (2003)

[5] Bogdan, Robert C. \& Sari Knopp Biklen : Qualitative Research For Education. an intruduction to theory and Methods. Allyn and Bacon. Boston. (1982)

[6] Elizabeth K. Nottingham : Religion and Society. an introduction to sociology of religion. Rajawali. Jakarta. (1990)

[7] Faisal, Sanapiah : qualitative research. Basics of application. Yayasan Asiah Asah Asih Asuh. Malang. (1990)

[8] Faisal, Ismail : the future of complexity of modernity challenges. Bakti Aksara Persada. Jakarta. (2003)

[9] Gerald O'Collins \& Edwar G. Farrugia : Dictionary of theology. Kanisius. Yogyakarta. (1996)

[10] Hasan Shadely : Sociology for Indonesian People. Bina Aksara. Jakarta. (1989) 
[11] Hendropuspito. D. : Sociology of Religion. Kanisius. Jakarta. (1983)

[12] Honig.AG., Science of Religion. Gunung Muliad. Jakarta (1992)

[13] Decision of the Director General of Islamic Community Number 379 Year 2018 about the implementation instructions of pre-marital course for bridegroom

[14] Lincoln, Y. S. and E. G. Guba. : Naturalist Inquiry. Sage Publication. (1985)

[15] Moleong, Lexy : Method of Qualitative Research. PT. Remaja Rosdakarya. Bandung.(2004)

[16] Nur Cholish Madjid : Islam Doctrine and Civilization. Paramadina. Jakarta. (1992)

[17] Patton, Michael Quinn : How to Use Qualitative Method in Evaluation. Sage Publications. Newbury Park. London. (1987)

[18] Regulation of the Director General of Islamic Community Guidance Number: DJ.II / 542 of 2013 about Guidelines for Pre-Marriage Course.

[19] Taufiq Abdullah (ed) : Religion, work ethic and economic development. LP3ES. Jakarta. (1988)

[20] Tangkilisan Hesel, Nogis : Management of Public. Gramedia Widya Sarana Indonesia. Jakarta. (2005)

[21] Thomas F.O'DEA : sociology of religion, an early introduction. Rajawali. Jakarta. (1985)

[22] Regulation Number 1 Year 1974

[23] W.J.S.Poerwadarminta : Indonesian General Dictionary. Balai Pustaka. Jakarta. (2006)

[24] Zuli Qodir: build discourse of open religion in shadow of power. Pustaka Pelajar. Yogyakarta. (2001) 